dissolved in formic acid, acetic acid and water is shown in Fig. 2. Mutarotation in glacial acetic acid solution was also observed in a poly-L-proline preparation obtained by polymerization in dioxane using triethylamine as initiator.

When the poly-L-proline sample obtained from the pyridine polymerization mixture by ether precipitation was dissolved either in hot glacial acetic acid or in metacresol at $100^{\circ} \mathrm{C}$. and reprecipitated from the cooled solutions by ether, it was found to dissolve readily in water. It gave $[\alpha]_{D}^{25}-500^{\circ}($ c. 0.5 in water $)$, $[\alpha]_{D}^{25}-450^{\circ}$ (c. 0.5 in glacial acetic acid) and $[\alpha]_{D}^{2 s}-525^{\circ}$ (c. 0.5 in formic acid).

In seeking an explanation of the above phenomena, a change in the chemical structure of poly-L-proline under the conditions leading to mutarotation can be ruled out. This is supported by the observation that all the forms of the polymer, on acid hydrolysis, yielded L-proline quantitatively. It seems reasonable therefore that the change in optical rotation is due to a change in the spatial configuration of the macro. molecule, connected possibly with a cis-trans transformation in the amide bond.

A helical structure based on the trans-form of the amide linkage was established for the highly lævoro. tatory form of poly-L-proline by Cowan and McGavin ${ }^{2}$ from the X-ray diffraction pattern given by oriented films of this polymer. It seems likely that the molecules of the highly lævorotatory form of the poly-Lproline have a similar helical structure also in water, acetic acid and formic acid. The poly-L-proline obtained in pyridine as described above probably represents an unstable form which changes into the more stable form under the influence of formic acid, acetic acid or water.

Woizmann Institute of Scienee,

JOSEPH KURTZ

ARIEH BERGER

Ephraim KatchaLSKI

Rehovot, Israel.

Aug. 10.

1 Berger, A., Kurtz, J., and Katchalski, E., J. Amer. Chem. Soc., 78, 6552 (1954).

- Cowan, P. M., and McGavin, S., Nature, 176, 501 (1955).

\section{Solubility of Albumin in Alcohol after Precipitation by Trichloroacetic Acid : a Simplified Procedure for Separation of Albumin}

RADIOACTIVE proteins are prepared for counting in many laboratories ${ }^{1-8}$ by slight modifications of the basic technique of precipitation with 10 per cent trichloroacetic acid, several washes with 5 or 10 per cent trichloroacetic acid, treatment with hot alcohol, hot alcohol-other and drying with ether. When it is required to remove nueleic acids, the protein is treated with 5 per cent trichloroacetie acid at $90^{\circ}$ for $15 \mathrm{~min}$. before the hot alcohol wash.

During an experiment in which rat serum proteins were being prepared for counting, we noticed that some of the protein precipitated by trichloroacetic acid dissolved in the absolute alcohol. We have observed this phenomenon repeatedly while preparing other samples for counting, but only if albumin is one of the proteins present. Albumin is also soluble in other solvents (acetone, ether) after precipitation by trichloroacetic acid and continues to be soluble even if higher concentrations of the acid are used to precipitate the protein. The precipitated albumin is only soluble in alcohol or the other solvents if a small amount of acid is present. Trichloroacetic, hydrochloric and acetic acids all work well in this respect. Treatment with 5 per cent trichloroacetic acid at $90^{\circ}$ for $15 \mathrm{~min}$. did not entirely prevent the albumin from dissolving in the absolute alcohol.

If the proteins are boiled, albumin will no longer dissolve in the acid-alcohol. It seemed possible that precipitation by trichloroacetic acid did not denature the albumin. Rat serum was therefore precipitated with 10 per cent trichloroacetic acid, centrifuged, the acid poured off and absolute alcohol added. ('The drop of acid remaining in the pellet is sufficient acid for our purpose.) The pellet was stirred and the undissolved protein spun down and the clear supernatant dialysed against distilled water for $24 \mathrm{hr}$. The dialysate was lyophilized and the dry protein powder examined. All the dry protein obtained by this means dissolved readily in water. Paper electrophoresis in $0.05 M$ veronal buffer at $p \mathrm{H} 7.4$ and at $p \mathrm{H} 8.6$ resulted in a single spot which was unretarded when compared with rat serum albumin separated by the Cohn procedure ${ }^{5}$ and with the albumin spot of rat serum. Addition of rabbit serum immunized with rat serum albumin produced precipitation of our albumin from the solution whereas rabbit serum without antibody caused no precipitation. The protein obtained by the method outlined appears to be undenatured rat serum albumin. Preliminary experiments indicate that the albumin is not con. taminated by other proteins. Similar findings were obtained with bovine albumin and human serum albumin.

We believe this simple procedure offers the basis for a rapid separation of serum albumin and a method for the detection and quantitative estimation of albumin in mixtures of other proteins; and we expect to publish full details of such methods at an early date. Meanwhile, we point out the necessity for care when preparing proteins for counting by the conventional techniques, especially if they contain albumin.

This work was supported by grants awarded to Dr. H. Tarver from the American Cancer Snciety.

A. KORNER*

J. R. Debro

Department of Physiological Chemistry,

University of California School of Medicine, Berkeley, California. August 13.

* Rockefeller Foundation Fellow 1955-56 ; present address : Department of Biochemistry, University of Cambridge, Cambridge, England.

'Brunish, R., and Luek, J. M., J. Biol. Chem., 198, 621 (1952).

"Abdou, I. A., and Tarver, H., J. Biol. Chem., 190, 769 (1951)

- Green, H., and Anker, H. S., J. Gen. Physiol., 38, 283 (1955).

- Schneider, W. C., J. Biol. Chem., 161, 293 (1945).

- Cohn, E. J., Strong, I. E., Hughes, Jun., W. L., Mulford, D. J., Ashworth, J. N., Melin, M., and Taylor, H. L., J. Amer. Chem. Soc., 68, 459 (1946).

\section{Molecular Weight Determination of Components by Gas-Phase Chromatography}

THE gas-density balance apparatus developed by Martin and James ${ }^{1}$ for detection and estimation of components in gas-phase chromatography might be used for a rapid process for evaluating the molecular weights of single components.

It has been shown that in a detector, which makes use of a gas-density balance, if the densities of two gas streams coming out of two columns, one where 